\title{
Why do female students choose to study CS in the Kingdom of Saudi Arabia?
}

\author{
Fayiq Alghamdi \\ Uppsala Computer Education Research Group, UpCERG \\ Uppsala University, Dept. of Information Technology \\ Uppsala, Sweden \\ fayiq.alghamdi@it.uu.se \\ Also affiliated to Al-Baha University, Dept. of Education \\ Al-Baha, Kingdom of Saudi Arabia
}

\begin{abstract}
We know that female students in computer science, $\mathrm{CS}$, are fewer than male students in Western countries. What is not well understood is the high rate of Saudi female students in CS. This article explores why female students choose to study CS in the Kingdom of Saudi Arabia, KSA. Data was collected through structured interviews with ten female students in three different universities in the KSA. The content analysis approach was used. This study determines the students' experiences in studying CS. The findings of this study are a first step in paying more attention to the system of women's education in the KSA. Motivation and expectation regarding CS were investigated. Results showed that the reasons behind the engagement of Saudi female students in CS are government support, family influence, and a stable workplace. The results could help to improve the CS curriculum and program of preparation for CS teachers in the KSA.
\end{abstract}

Keywords : CS , CSE, KSA, female education.

\section{INTRODUCTION}

Women are reported to be fewer than men in Computer Science, CS at the tertiary institutions in Western countries. In statistic reports state that CS students were female only $14 \%$ of U.S. [1], 16\% of U.K. [2], and 14\% of Swedish in 2014 [3]. On the other hand, in the Kingdom of Saudi Arabia, KSA, 45.8\% of the students in CS were female also in 2014 [4]. Compared to the KSA, there are significantly fewer CS female students in the U.S, the U.K, and Sweden.

A study conducted by Varma reported that the CS environment in India is a more fitting workplace for women than men and provides excellent opportunities for Indian women regarding future employment [5]. There are also sizable numbers of female students in CS in Malaysia, and Mellström argues that the reason why there are students in Western countries are biased in gender in CS, and she sees this difference as a cultural one [6].

In the KSA, female citizens do not have equal opportunities in the labor market compared to men, but Saudi women work as businesswomen, doctors, engineers, politicians, etc. In higher education, there are over 20000 female faculty members, corresponding to $44 \%$ of faculty [7].

Today, CS is playing an important role in the world and has led to a technological revolution. Many countries respond to this by improving CS education. In the KSA, forty-two colleges offer CS programs all over the country, which is suitable for students who seek enrollment near their home cities [7]. As a result of the technological revolution development, many studies investigate why students choose CS in different countries. Kinnunen et al. show the students' expectations and careers from the first year of CS study in three European countries (the U.K, Sweden, and Finland). The outcome underlines that a positive impression of studying CS is needed for engagement in CS[8]. Beyer's study states if a woman has a good technical background in CS, she will choose to study CS [9]. To sum up, there is a connection between students' knowledge of CS and students' choosing to study CS.

\section{SOCIETY AND CULTURAL FACTORS IN THE KSA}

The KSA is located in the Middle East. It is approximately $2,150,000 \mathrm{~km} 2$. The population is $31,742,308$, of which $63 \%$ are Saudi citizens. The official language is Arabic [10]. The constitution and the law in KSA derive from the Islamic laws [11]. In the KSA, the Islam religion dominates individual's behavior, and it sets special rules. For example, education is gender separated.

Women's education has been affected by the Islamic customs and traditions. Alhareth [12] and Katalin [13] agreed that the aspects of society and cultural factors affecting female education in the KSA are religion, family, education, and transportation.

In the present era, globalization and modern interpretations of Islam in the KSA encourage female education. The KSA invests in women's education, particularly women's higher education. The KSA government is expanding the number of universities and opportunities for studying abroad. In the education policy document established in 1969, there is a section specifically on 
female education which states: (1) Female education should provide appropriate jobs for female students. (2) There should be gender-separation in education [7]. The historical development of female education in the KSA is as follows:

- In 1949, pre-formal female education started.

- In 1959, schools for women were opened systematically. An agency called the General Presidency for Girls' Education managed female education.

- In 1999, the first female university in KSA was opened.

- In 2002, the Ministry of Education and the General Presidency for Girls' Education were merged.

Nowadays, there is one ministry of education in the KSA for males and females. The ministry directs general and higher education in the KSA. The number of schools is 35500 , and 18,710 are female schools. There are 42 universities and 19 private colleges. Three of the universities are dedicated to female students: The Effat and Dar Al-Hekma are private universities, and Princess Nourah Bint Abdulrahman University, PNBAU in Riyadh is the world's largest female university [7]. Other universities have two gender-separated campuses.

\section{RESEARCH QUESTION}

The purpose of this project is to explore how a Saudi female student perceives CS education through their engagement, experience, and expectation. The project will also look individually at how female students learn CS and collaboratively in the discipline and context in CS. This project will also look at the high rate of female students in CS. In this first paper, the question is: Why do female students choose to study CS in the KSA?

\section{RESEARCH Methodology}

\section{A. Data collection method}

Interviews are one of the several ways to gather data from participants. An interview is a tool for collecting data which specifically involve asking questions. [14]. There are three types of interviews: structured, semi-structured and unstructured. In this study, structured interviews conducted by e-mail or phone call were used. These methods are suitable for this study because it was difficult to communicate with female students face to face with the KSA culture. Men cannot allow interviewing in the female section in school or university. Structured interviews confer collection of responses to compare and contrast [15]. The questions were open-ended and related to participants' background in CS education and expectation in the future career. The same set of questions was asked in a similar order. The structured interviews were fifteen questions raised in the previous literature and the researcher's experience as an assistant teacher at Al-Baha University, ABU in the KSA. Indeed, the questions were discussed with the committee in Uppsala University Computer Education Research Group, UpCERG. The interview consists of three parts, each containing five questions to encourage the female students in their reflections and decisions that led them to choose to study CS. The data were gathered during summer 2016.

\section{B. Participants}

The CS accounts on Twitter were the way to publish a link announcing for CS teachers, students and colleges. The volunteers - who want to participate in this study - were given their acceptances along with the best way to contact them by email or phone call. As a result, only twenty-three female students were volunteered. The twenty female students' volunteers were preferred answering the interview by the e-mail and three by the phone call. Consequently, only ten participants out of twentythree were completed the interview questions, nine participants by the e-mail and one participant was interviewed by the phone call. The participants were ten female students from three different universities: Al-Baha University, ABU - Princess Nourah Bint Abdulrahman University, PNBAU - Al-Imam Muhammad Ibn Saud Islamic University, AMISIU.

\section{Qualitative content analysis}

The content analysis approach was used to summarize the content by considering various aspects of the content. The main idea for the content analysis is dividing the material into categories. There are two types of content analysis which are inductive category development and deductive category application [16]. In this paper, the deductive category development used. See it in figure 1.

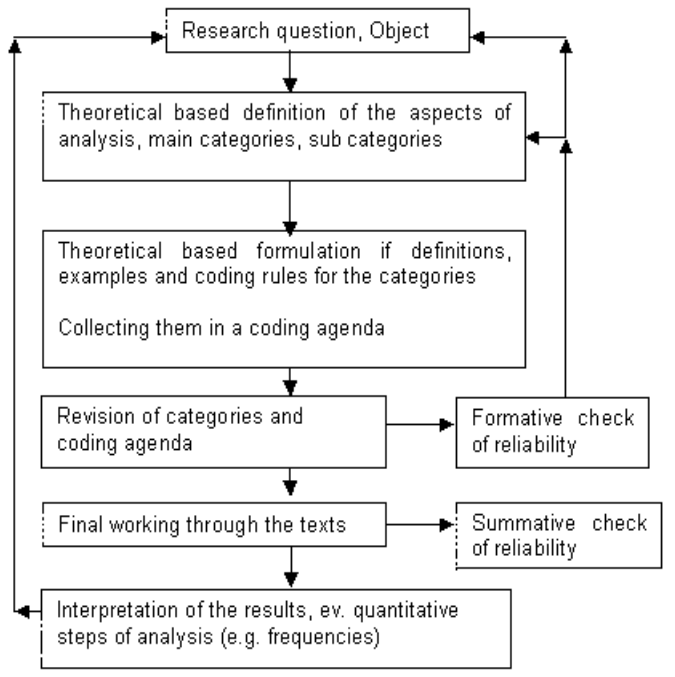

FIG. 1. MODEL OF DEDUCTIVE CATEGORY APPLICATION (MAYRING 2000) [16] 
The deductive category development has been used as a framework in Kinnunen et al. study [8]. The deductive category development is inspiring to look for comparison and contrast. This type will answer to where categories come from in this study and what are the similarities and differences between these two studies. In practice, all the answers were put in the Excel sheet in the Arabic version and translated to English word by word as much as the meaning does not change. All the answers were printed out and read through them several times. The relevant answers were grouped together which have as similar meaning. The data were compared with the Kinnunen's framework. In the framework of Kinnunen et al. study, they mentioned two categories, five sub-categories and thirty themes. The data came from three different countries (the UK, Finland and Sweden) and the participants were 482 students. The categories were motivation and expectation. The motivation is with the undertaking CS studies, the interest in specific study content and the expectation of broad study content. On the other hand, the expectation category is with the job duties and the career expectations. See the table 1.

\section{TABLE I. THE FRAMEWORK OF KINNUNEN ET AL.}

\begin{tabular}{|c|c|c|}
\hline Category & $\begin{array}{c}\text { sub- } \\
\text { categories }\end{array}$ & Themes \\
\hline \multirow{3}{*}{ Motivation } & $\begin{array}{l}\text { Undertaking } \\
\text { CS } \\
\text { Studies. }\end{array}$ & $\begin{array}{l}\text { General IT interest } \\
\text { Specific content interest } \\
\text { External influence } \\
\text { Characteristic of IT } \\
\text { Tangential reason } \\
\text { Career aspiration } \\
\text { No response } \\
\text { Other }\end{array}$ \\
\hline & $\begin{array}{l}\text { Interest in } \\
\text { specific } \\
\text { study } \\
\text { content. }\end{array}$ & $\begin{array}{l}\text { Programming } \\
\text { Computing systems } \\
\text { CS Special area } \\
\text { Software development Human- } \\
\text { computer interaction General } \\
\text { interest } \\
\text { Unsure } \\
\text { Mathematics } \\
\text { No response } \\
\end{array}$ \\
\hline & $\begin{array}{l}\text { The } \\
\text { expectation } \\
\text { of broad } \\
\text { study } \\
\text { content. }\end{array}$ & $\begin{array}{l}\text { Technical } \\
\text { Professional } \\
\text { Unsure } \\
\text { Research } \\
\text { No response }\end{array}$ \\
\hline \multirow[t]{2}{*}{ Expectation } & Job duties & $\begin{array}{l}\text { Software designer } \\
\text { Project manager, manager } \\
\text { Entrepreneur } \\
\text { Programmer } \\
\text { Administrator } \\
\text { Solving societal problems } \\
\text { Researcher } \\
\text { Teacher, educator } \\
\text { Something else } \\
\text { I do not know }\end{array}$ \\
\hline & $\begin{array}{l}\text { Career } \\
\text { expectations }\end{array}$ & $\begin{array}{l}\text { Specific job type (e.g. consultant) } \\
\text { Specific job characteristic } \\
\text { Unsure } \\
\text { Specific type of work } \\
\text { environment } \\
\text { Start-up/entrepreneurship } \\
\text { No answer }\end{array}$ \\
\hline
\end{tabular}

The categories of this paper are agreed with Kinnunen et al. study. It is clear that the motivation and expectation are the same between this study and Kinnunen et al. but the difference is in the external influence theme and environment theme.

\section{RESULTS}

It became apparent that numerous topics mentioned belonging to two categories and the categories contend subcategory. The two categories show in this study are motivation and expectation. Each of these categories covered four to three sub-categories recognized presented in the table 2 :

\section{TABLE II. CATEGORIES AND SUB-CATEGORIES IN THIS STUDY}

\begin{tabular}{|c|l|l|}
\hline Category & \multicolumn{1}{|c|}{$\begin{array}{c}\text { sub- } \\
\text { categories }\end{array}$} & \multicolumn{1}{c|}{ Explanation } \\
\hline \multirow{4}{*}{ Motivation } & $\begin{array}{l}\text { General CS } \\
\text { interest }\end{array}$ & $\begin{array}{l}\text { Fun, desire, need, programming and } \\
\text { web development }\end{array}$ \\
\cline { 2 - 3 } & $\begin{array}{l}\text { Career } \\
\text { aspiration }\end{array}$ & More opportunities in labor market \\
\cline { 2 - 3 } & $\begin{array}{l}\text { Family } \\
\text { influence }\end{array}$ & $\begin{array}{l}\text { Encourage to study CS from family } \\
\text { or friends }\end{array}$ \\
\hline \multirow{4}{*}{ Expectation } & Future job & $\begin{array}{l}\text { Software designer, programmer, } \\
\text { entrepreneur, teacher, others }\end{array}$ \\
\cline { 2 - 3 } & Workplace & $\begin{array}{l}\text { being safe, choosing work with a } \\
\text { man or not and working alone }\end{array}$ \\
\cline { 2 - 3 } & Skills & Technical, nontechnical skills \\
\hline
\end{tabular}

1) Motivation

In the interview, students were asked questions on many aspects relating to their experience when they chose to study CS. For example: Do you have the interest in studying CS? Who does influence you to study CS? What do you expect to learn from CS? All these questions are focused on stages before the female students joined the universities and at the beginning of their first year at CS colleges. The qualitative content analysis highlighted three sub-categories in the motivation category which are (General CS interest - Career aspiration - External influence). The most frequently mentioned reason has been general CS interest which contents fun, desire, need, programming and web development, such as:

Student A:

Student B

The desire for development and evolution.

Student C:

CS gives benefits to our society.

It gives an excellent feeling to achieve the objective of the project.

In career aspiration, the female students mentioned the labor market.

Student J:

A girl is most likely choosing CS because it is a required in the labor market to be specialization. It also allows female choose her job, ... I chose CS because it is my passion and I want to learn the computer as a hobby and study.

Student C:

Perhaps because it suits the capabilities and ambitions of others, ... I chose it because it is special to me and I find myself in CS.

Some students revealed that they would be working in a company.

Student D: 
Student F:

My job will be in a large company.

I might be working in a company.

Also, three students said they would work in school or university.

In external influence the female students choose CS referred to family support.

Students A:

Yes, there are CS graduates among my family and relatives who have encouraged me a lot, particularly my brother who kindly Student C: bought me a laptop as a gift symbolizing my specialist.

My parents were the first to encourage me to study CS and the first who guided me in that way, sometimes by motivational dialogue to read a lot about CS, and others by talking to me about CS as one ... Without their help and encouragement, I would not realize the importance of CS or know anything about it, nor I would be teaching it now.

One female student stated that the CS was the second choice after when they did not gain acceptance in medical education. The female student sees the medical education is more comfortable workplace for her than CS:

Student E:

In the first, I did not choose to study CS, but I liked it. It was my second option after medicine because it is the most important discipline that serves people.

Another female student stated that the CS is the new major at the University

Student J:

\section{2) Expectation}

It is a new major in the university.

It is observed from the data when female students were asked questions relating to the expectation in the future career and education environment. For instance: What kind of skills do you expect to acquire after you will graduate? Could you describe how do you see yourself in the workplace in the future?

The qualitative content analysis emphasized three subcategories, which are (Future job - Workplace - Skills). The most frequently mentioned reason has been the future job, Student A:

Student E:

A girl chose to study CS because it is a safe way to enter the job into the labor market quickly compared to other disciplines...

I am interested in CS because it provides jobs everywhere.

In the workplace, participants referred to being safe, choosing work with men or not.

Student J: Student B:

Whether she prefers to mingle with men or not

A girl chose CS because it is suitable for a work environment where there is no mingling with men, and the job does not need any physical efforts, just sitting down and accomplishing tasks on computers.

The participants also stated that women professors are closer to students in the female section on campus rather than men that makes the communication easy and fast to answer questions, Student A:

Yes, there are women and men professors, and there are reasons of preference for each. While men teachers teach easier, female professors are more engaged in direct contact with the students. In my point of view, I prefer men teachers for the easy method of teaching.

Student F:

Yes, there are male and female professors. I prefer female because I communicate easier with them and talk about any problem in Student C: lectures or tests and share projects with them if I need.

Yes, there are. I prefer female professors because I can communicate directly with them and understand better as well. They are always present where I can go to see them anytime, unlike male professor that I have to send emails or go to see them at lecture time only.

Some of the participants do not feel big issue when they taught by men professors. The men professors have all possibilities tools to teach CS for female students such as a video conference, speaker and female assistant in the female section. Student C:

Student H:

...., there is no difference between them except in how they can provide a sufficient and adequate explanation of the material taught.

Yes. Men and women have taught me at college. There is no difference between them in teaching...

In skills part, the participants referred to CS skills and communication skills. In CS skills, the female students involved in programming, developing and analyzing.

Student A:

Student E:

Programming of sites and apps, and systems analysis. Student F:

Problem-solving; Data analysis; Many programming languages.

Programming, feasibility study, analysis, designs, create websites and applications.

Also, the participants expected to gain several skills during their education which are related to communication.

Student D:

Student B

Working with a team and time management.

Student D

Leadership and presentation skills.

Working with a team under pressure.

In the following section, the results have been discussed with the literature review and the researcher experience.

\section{DISCUSSION}

Motivation and expectation regarding CS female education were investigated in this study. The motivation referred to the rapidly developing field and affected the world society. Development and investment have moved female students to choose CS. The KSA government supports CS education. CS colleges have been expanded from seven in 2005 to forty-two colleges today [7]. The Ministry of Education in the KSA established a Saudi Computing Colleges Committee, SCCC in 2014 to encourage and raise the level of performance in both 
students and staff. The SCCC has a core aim to increase the quality of CS education in the KSA.

The technological revolution and rapid expanse were mentioned by the participants as reasons for choosing to study CS. A family encourages their children to choose to study CS in the KSA. Almost all participants agreed that it was their families that inspired them to choose to study CS. The participants want to contribute to solving the problems that face the world in daily life.

As a result, a separate environment in CS colleges and workplace were confirmed as being a reason for choosing to study CS in the KSA. The CS workplace gives female students the option of working with or without men. It was reported that $53 \%$ of the women in the KSA prefer to work without men in the workplace, and $55 \%$ of the guardians favors work without men [17]. The participants had the desire to establish their own businesses when they had acquired the abilities and skills provided in CS.

\section{CONCLUSION}

This paper was investigated why female students in the KSA chose to study CS. This is the first study on CS education among female students in the KSA. The researcher acknowledges that the number of participants was few and that a deeper investigation is needed. However, the result is contributing significantly to the field of study. The outcomes of this study analyze the high rate of female CS students in the KSA. The reason why female students choose to study CS is because the CS field has government support, because of family influence and because the environment is a stable workplace. This study would suggest that the KSA needs to improve the CS curriculum in schools and universities, in order to achieve high quality and contemporary CS education, and that collaboration must be established with the top universities that specialize in $\mathrm{CS}$ around the world. The KSA should also review the program that prepare CS teachers, in order to reach the highest impact of CS in schools and universities. In the future, I will look at the competencies of CS teachers in the KSA and how CS teachers can develop professionally in their careers.

\section{ACKNOWLEDGMENT}

I would like to thank Anders Berglund and Aletta Nylén for many inspiring discussions, comments and time.

\section{REFERENCES}

1. National Center for Science and Engineering Statistics (NCSES), "Science and engineering indicators", Arlington, VA, 2014

2. Universities UK (UUK), "Patterns and trends in UK higher education", London, the U.K, 2015.

3. Educational Statistics in Sweden, "Utbildningsstatistisk årsbok”, Educational Statistics Yearbook, 2015, (In Sweden).

4. F. Alghamdi, "Women in computing in Saudi Arabia", Poster session presented at wonENcourage, $3^{\text {rd }}$ ACM-W Europe celebration of women in computing, Linz, 2016.

5. R. Varma, "Computing self-efficacy among women in India", Women and Minorities in Science and Engineering, vol. 16, no. 3, pp. 257-274, 2010

6. U. Mellström, "The Intersection of Gender, Race and Cultural Boundaries, or Why is Computer Science in Malaysia Dominated by Women?", Social Studies of Science, vol. 39, no. 6, pp. 885-907, 2009.

7. Ministry of Education, "احصائيات التعليم العالي في السعودية", Statistics university education in KSA, Ministry of Education, Riyadh, 2014-2015, (In Arabic).

8. P. Kinnunen, M. Butler, M. Morgan, A. Nylen, A. K. Peters, J. Sinclair, S. Kalvala \& E. Pesonen, "Understanding initial undergraduate expectations and identity in computing studies", European Journal of Engineering Education, pp. 118, 2016.

9. S. Beyer, "Why are women underrepresented in Computer Science? Gender differences in stereotypes, self-efficacy, values, and interests and predictors of future CS course-taking and grades", Computer Science Education, vol. 24, no. 2-3, pp. 153-192, 2014.

10. Ministry of Foreign Affairs, "About Saudi Arabia", available: http://www.mofa.gov.sa/sites/mofaen/ServicesAndInformatio n/aboutKingDom/Pages/KingdomGeography46466.aspx. [Accessed 2212 2016]

11. K. Y. Krivenko, Women, Islam and International Law, Montréal: Brill, 2008

12. Y. Alhareth, "E-Learning Enhancement of Higher Education Opportunities for Women in Saudi Arabia", US-China Education Review A\& B, vol. 3, no.9, pp. 637-648, 2013.

13. H. Katalin, "Improving intercultural competence of female university students in EFL within Saudi Arabia", ProcediaSocial and Behavioral Sciences, vol. 192, pp 554-566, 2015.

14. C. Mears, Research Methods and Methodologies in Education, in InterViews: Learning the Craft of Qualitative Research Interviewing, 2012, SAGE, 2012, pp. 170-175.

15. U.S. Office of Personnel Management, Structured interview, available:https://www.opm.gov/policy-dataoversight/assessment-and-selection/structured-interviews/. [Accessed 1310 2016]

16. P. Mayring, "Qualitative Content Analysis", Freie Universität Berlin, Available:http://www.qualitativeresearch.net/index.php/fqs/article/view/1089.[Accessed 2010 2016].

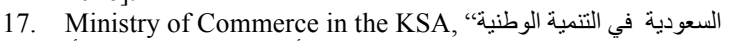
(دراسة استطلاع الرأي العام في مشاركة المرأة ," Public opinion, the study on the participation of Saudi Arabia Saudi women in national development, Jeddah, 2013, (In Arabic). 